

Figure 2: Core photo from Walvish Ridge (Ocean Drilling Program ODP Leg 208) with dark sediment representing the PETM, and calcareous nannofossils of Discoaster multiradiatus (Site 1263). (a) a relatively well-preserved, prePETM specimen; (b) a corroded specimen from the acidification event during PETM. Scanning electron microscope (SEM) images from Mascha Dedert, Vrije Universiteit Amsterdam.

Stephen Barker (Cardiff University) illustrated widespread deep ocean acidification and resulting dissolution of carbonate sediments during the Mid-Brunhes interval ( 0.6-0.2 Myr ago). This global change in ocean carbonate chemistry may have been driven by an increase in pelagic carbonate production caused by the proliferation of the calcifying Gephyrocapsa coccolithophore. This example provides a case for: (1) how profound changes in biology can drive (or feedback on) OA, and (2) how changes in the calcifying planktonic ecosystem can influence the balance between the organic and inorganic carbon pumps and hence ocean-atmospheric $\mathrm{CO}_{2}$ exchange and global climate.

Carles Pelejero (CMIMA-CSIC Barcelona) gave an example of an $\mathrm{OA}$ study from the historical past. A 300-year reconstruction of $\mathrm{pH}$ from boron isotopes in corals biological calcification responses before we will be able to reduce the uncertainties in our models.

According to Richard Zeebe (University of Hawaii) none of the past OA scenarios will be able to depict the true extent of future acidification. The injection of carbon into the ocean-atmosphere system, even during the PETM, was most likely not as rapid and intense as the modern situation. A more gradual release of carbon would have been more efficiently buffered by deep sea carbonate dissolution, resulting in a reduced effect on surface ocean $\mathrm{pH}$. A noteworthy implication of this is that any effect on marine biocalcification during past OA events, including the PETM, may represent the very minimum response that might be expected in the future.

Particular emphasis was given to considering the geographical distribution of any event in terms of response in the system. For example, the extent of carbonate dissolution during the PETM was not equal globally. Although none of the past OA analogs seem to be able to depict the true extent of future acidification, they all provide important constraints on the nature of the threat for the near and distant future. These constraints are also critical in order to assess planktonic species adaptation rates to such perturbations, putting our ability to understand the future on firmer ground.

\section{References}

Kroon, D., Zachos, J.C. and Leg 208 Scientific Party, 2007: Leg 208 synthesis: Cenozoic climate cycles and excursions, In: D., Kroon et al., (Eds), Proceedings of the ODP, Scientific Results, 208: College Station, TX (Ocean Drilling Program), 1-55, doi:10.2973/odp. proc.sr.208.201.2007

Ziveri, P., et al., 2007: Atmospheric CO, ocean acidification, and ecological changes in planktonic calcifying organisms, The Eggs, 22 (21 December): http://the-eggs.org/articles.php?id=112

Ziveri, P., Young, J., Fabry, V., Bijma, J., Turk, D., Kiefer, T. and Eisenhauer, T., 2008: Understanding Marine Biotic Responses to Fossil Fuel Emissions, Eos, Transactions, American Geophysical Union, 89: 127.

\title{
Oceanography and Climate Change: Past, present and future scenarios
}

\section{Austral Summer Institute VIII, Dichato, Chile, 7-14 January 2008}

\section{Sergio Contreras Quintana (Workshop Participant)}

Department of Biogeochemistry, Max Planck Institute for Marine Microbiology, Bremen, Germany; scontrer@mpi-bremen.de

The Austral Summer Institute VIII on "Oceanography and Climate Change: Past, present and future scenarios" was held in Dichato, Chile, from 7 - 14th January 2008. Twenty students were selected from 92 applicants to participate in the workshop, which also involved the participation of word-class lecturers.
The first week focused on two key topics:

1) El Niño Southern Oscillation, theory, observations and predictions was lectured by Dr. Axel Timmerman, from the University of Hawaii. Lectures were complemented with computer-based exercises and homework, including ocean and atmosphere data analyses and simple model runs for ENSO predictions.

2) The role of the thermohaline circulation on the Earth's climate was lectured by Dr. Andrey Ganopolsky from the Potsdam Institute for Climate Impact Research. This included a discussion of climate consequences in modern times 




Students and lecturers of the Austral Summer Institute VIII and in future climate scenarios, and was complemented by student discussion sessions on predefined topics.

On the last day, the team project "Congress hearings on thermohaline ocean circulation" was organized. Students prepared independent arguments for and against the importance of the ocean thermohaline circulation and made presentations to argue their cases.

The second week focused on the theory of the Milankovitch cycle as the main main biogeochemical cycles in the modern ocean and how they can affect the cli- mate system. Most of these lectures were also complemented with exercises.

The course included "Distinguished Lectures on Climate Variability" delivered at the main campus of the University of Concepcion. The purpose of this was to offer these presentations to a wider audience. In addition to listening to Dr. Sarmiento and Dr. Berger, we were able to learn from Chilean experts about the analysis of the biological and societal consequences of global change. This proved to be a good experience for class participants, as well as for the other professionals and students who were able to attend.

I would like to thank the University of Concepción and PAGES for providing me with the opportunity to attend this workshop. I feel that attending the course gave me a broader perspective on climate change, which has strengthened my background in paleoceanography. In my opinion, this type of activity, in which students and professors interact in a friendly, informal environment outside the classroom, facilitates communication, and results in professional development and joint research enterprises.

\section{New on the PAGES bookshelf}

\section{Historical and Holocene glacier-climate variations \\ Editors: C. Kull, O. Solomina, W. Haeberli and G. Wiles \\ ELSEVIER Press}

This special issue of Global and Planetary Change provides an overview of recent research activities concerning changes in the timing of glacier changes and their linkages to climate. The contributions are based on presentations from two glacier-climate-cryosphere sessions co-organized by the EU-funded GLOCHAMORE project (Global Change in Mountain Regions), PAGES and the WGMS (World Glacier Monitoring Service) at the Open Science Conference on "Global Change in Mountain Regions" organized by the MRI (Mountain Research Initiative) and held in Perth, Scotland, 2-6 October, 2005.

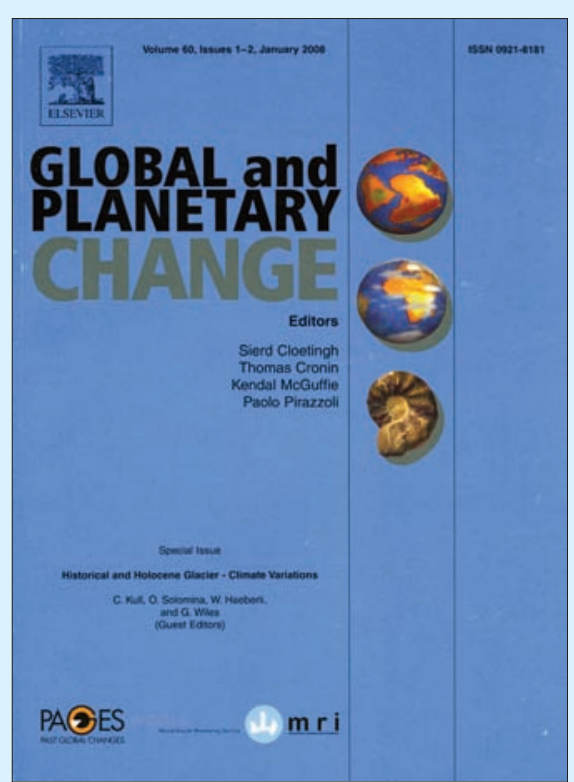

\section{Summary of Contents:}

- Historical and Holocene glacier-climate variations; O. Solomina et al.

- Norwegian mountain glaciers in the past, present and future; A. Nesje et al.

- Strength and spatial patterns of the Holocene wintertime westerlies in the NE Atlantic region; J. Bakke et al.

19th century glacier representations and fluctuations in the central and western European Alps; H.J. Zumbühl et al.

- Palaeoclimate from glaciers: Examples from the Eastern Alps during the Alpine Lateglacial and early Holocene; H. Kerschner and S. Ivy-Ochs

- Recent glacier changes and climate trends on South Georgia; J.E. Gordon et al.

20th-century glacier recession and regional hydroclimatic changes in northwestern Patagonia; M.H. Masiokas et al.

- Tracing tropical Andean glaciers over space and time; B.G. Mark

Century to millennial-scale temperature variations for the last $2000 \mathrm{yrs}$ from glacial geologic records of Southern Alaska; G.C. Wiles et al.

- Late Holocene monsoonal temperate glacier fluctuations on the Tibetan Plateau; B. Yang et al.

- A brief consideration of climate forcing factors in view of the Holocene glacier record;

A.T. Grove

- Late Pleistocene glaciation in the Central Andes: Temperature versus humidity control; C. Kull et al. 